\title{
Analysis of Financial Aspects Feasibility Lawang Oil Factory in Manokwari District, West Papua
}

\author{
Niclason F. F. Iwanggin, Afrizal Abdi Musyafiq, Arief Budiman, Rochim Bakti Cahyono \\ \{niclason.filex.f@mail.ugm.ac.id ${ }^{1}$, afrizal.abdi.m@gmail.com ${ }^{2}$ \} \\ Departement Master of System Enggineering, Universitas Gadjah Mada Yogyakarta, Indoensia ${ }^{1}$, \\ Departement Electrical Engineering, Universitas Nahdlatul Ulama, Yogyakarta, Indoensia ${ }^{2}$, Departement \\ Chemical Engineering, Universitas Gadjah Mada, Yogyakarta, Indoensia ${ }^{3,4}$
}

\begin{abstract}
Small industries in the form of food and herbal industries in Manokwari regency in 2014 totaled 123 business units by absorbing 360 workers. One of the objectives of the investment is to develop and manage forest products such as essential oils derived from spices such as lawang skin oil obtained from the distillation of bark of bark. The increasing demand for essential oils at home and abroad each year can be used as an opportunity and business potential in Manokwari. The purpose of this study was to find out the data of financial studies and find out the sensitivity data of lawang oil. The method used was field observations in Windesi District, West Papua; as well as analyzing data processing with qualitative and quantitative methods. The qualitative method is used in the process of lawang oil refining, a quantitative method to determine the quality of the production of lawang oil financially based on business feasibility analysis. The results of this study are the Lawang Oil Business in fianasial feasibility in Manokwari Regency in the estimation of operating period of the 2018-2022 operating year can be said to be profitable. This is based on the analysis of NPV (Net Present Value) of $10 \%$ or as much as Rp. 2,727,272,727; Net B/C (Net Benefit Cost/Ratio) is $10 \%$ or equal to 2.82; IRR (Internal Rate Return) is $12 \%$; and the payback period is 4.5 years. Lawang oil business in its orientation certainly has favorable prospects and can be developed as long as the selling price of the product does not exceed $8.62 \%$ and the increase in operating costs does not exceed $91.3 \%$.
\end{abstract}

Keywords: Financial Feasibility Analysis; Lawang Oil; Manokwari Regency; Net Present Value; Net Benefit Cost/Ratio

\section{Introduction}

Indonesia is a country rich in natural resources such as wealth in the field of flora and fauna [1]. The source of Indonesia's natural wealth is very wide spread throughout the country, especially in the Papua Islands. This source of natural wealth can be utilized as industry standards, food sources, and trade sources that generate state foreign exchange and can drive the country's economic growth [2]. Indonesia is famous for producing various types of spices that are well-known and sought after by many people, especially from abroad, as well as various types of essential oils [3]. Essential oils are also referred to as oils that have volatile properties because they consist of a mixture of volatile substances with different composition and boiling points [4]. Essential oils are often used as perfumes, cosmetics, food, aromatherapy and medicines in this era [5]. Essential oils have been developed and become Indonesian export commodities which include essential oils from wood, mace, patchouli [6], fragrant roots [7], 
nutmeg [8], cloves [9], citronella [10], kenanga [11], wood white [12], sandalwood [13], pepper [14], and cinnamon [15].

Consumer demand for essential oils is increasing. Likewise, the price of essential oils made from the bark of barang wood is increasing [16]. The limited production of raw materials is one of the factors that make this essential oil has a high selling value [17]. This has triggered the emergence of small industries that continue to innovate this essential oil. the development of the national essential oil industry, especially in the field of making mace oil already exists in Indonesia. Classification of essential oil management and processing in Indonesia There are already 7 trade names registered and operating industrially. Until now there are 18 lists of trading businesses or the management and processing of essential oils that are in the development process in Indonesia. There are 9 lists of trading businesses or the management of essential oils that are under development to be commercialized in Indonesia [18].

Based on data from the Ministry of Trade, the export value of essential oils, cosmetics, fragrances from 2010 to 2014 has increased every year [19]. For example in 2013 the export value was US \$ 604.1 million, then in 2014 it increased to US \$ 659.8 million. This shows that essential oils have good prospects to develop. Plants that produce essential oils that are widely cultivated in Indonesia, one of which is the bark of the lawang plant. The bark of the mace plants is widely planted in various parts of the Papua islands [20]. This essential oil is produced from the refining process [21]. The distillation process is the result of the separation of essential oils and aromatic plant material [22]. In the process of essential oils, there are two ways of processing that are commonly carried out in traditional refineries [23]. There are three general methods for extracting lawang wood namely water distillation [24], steam distillation [25], and distillation of boiling water [26]. This immersion process aims to soften the gland tissue lining the oil on the wood. So that later it is expected that water will become easier to transport oil contained in raw materials [27].

Papua Island is one of the main islands in the Indonesian Archipelago which has high potential of genetic resources (SDG) for agricultural crops, which is indicated by the variety of agroecosystem conditions ranging from lowlands to dry, wet and swampy ecosystems up to $4000 \mathrm{mdpl}$ (meters above sea level) with the alpine ecosystem. In general, the peculiarities of this region have been marked differently to other regions in Indonesia by the lines of Webber and Wallace. The Papua Islands have a variety of plants that can be used as industrial raw materials, especially in Manokwari Regency. The area of Manokwari Regency is mostly located on the plains of the island of Papua. There are 13 mountains with the highest mountains are Mount Umsini and Mount Mamofcu, which have an average height of 2,950 masl and 2,985 masl. In addition, there are 15 rivers and the longest river is the Wariori river which has a length of $96 \mathrm{~km}$ lying in the Masni District. There are also 6 lakes in Manokwari district and the largest lake is Anggi Gida lake with an area of 2,500 ha located in the Anggi District. Air Humidity in Manokwari is relatively still in the range of $80 \%$. The biggest air humidity occurred in February which reached 94\% and the lowest in April with humidity reaching 74\% [28].

Potential information The lawang tree (Cullilawang Cinnamonum) is not yet accurate in its distribution, but its natural growth takes place sporadically in several regions in the provinces of Papua and West Papua. Based on the results of monitoring the centers of lawang oil production have been identified that the potential of lawang wood is promising and can be developed into local / local community plantations. The centers of production and distribution of lawang wood in the area / location are in: Kaimana Regency, Fakfak, Bintuni Bay, Wasior Regency, Sorong, Manokwari and partly in the forest area of Raja Ampat Regency (West Papua) [28]. At least 1,200 Lawang trees were planted in the sub-district of Warmare Sub-district, Manokwari in December 2014. The planting was part of the national tree-planting day as well 
as the planting of trees in 2014 at the level of West Papua Province and precisely in Manokwari district. This activity which was driven by the West Papua Provincial Government involved various community groups including students, environmentalists, forest farmer groups, and local communities. This activity certainly aims to be able to introduce further in increasing the utilization of the potential of the lawang tree plant. Considering the potential and availability of abundant raw materials in the West Papua region, it is possible to plan a small or medium-sized business for the management and processing of the lawang bark. Lawang tree plants grow wild in the forests of Kaimana Regency, Bintuni Regency, Wasior Regency and Manokwari Regency [28]. Until now, the business of processing the lawang oil run by the community is still small and there are only 2-3 businesses built in each region. And even then with the process of processing that still uses traditional methods in the processing process so that the production of lawang oil does not have maximum quality. In addition, there are other constraints that cause the supply of raw materials at high prices because the location of raw material is far away and must walk at a distance of $\pm 4-5 \mathrm{Km}$ into the forest area even through mountain areas and hills and valleys to get trees Lawang wood that is suitable for processing [28]. 1.

The map of the distribution area of lawang trees in West Papua Province is shown in Figure

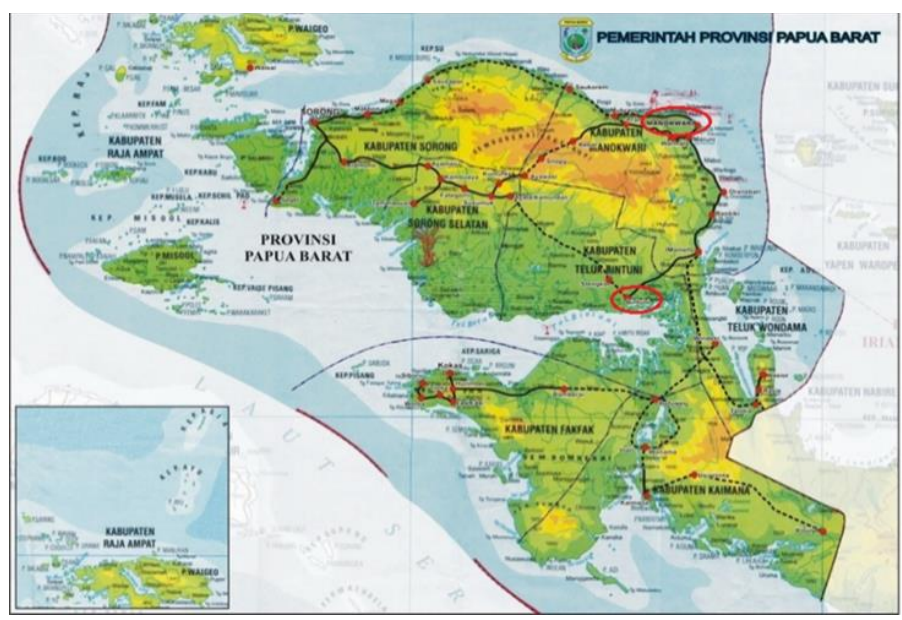

Fig. 1. Areas of distribution of lawang trees in West Papua Province [28]

\section{Method}

This research was conducted in Windesi Subdistrict, Wasior Regency, West Papua Province. The observation process (observations) lasts for 2 weeks which is adjusted to the time of the process of processing the distillation of the lawang oil by utilizing lawang tree trunks. Primary data is obtained through field surveys. The method used for primary data collection is interviews and field observations. The data that has been obtained is calculated from October to November 2017. The data is secondary data derived from literature, the internet and other literature related to lawang oil and also a business feasibility study. Processing of data analysis in this study was carried out with qualitative and quantitative methods. The qualitative method is used in the process of lawang oil refining, while the quantitative method is to find out the quality of the production of lawang oil financially based on the business feasibility analysis. 
Qualitative data such as analysis of market aspects, technical aspects, aspects of raw materials, management aspects, and socio-cultural aspects of the economy are described descriptively. Quantitative data processing is carried out with mathematical and statistical computing programs for cashflow [29] and forecasting [30] on total costs and market prospects for the next few years. This information data aims to classify it to make it easier to analyze data.

Investment is obtained by calculating the cost of invested capital and profits from sales that are adjusted to several important targets including the market; production; employees; accommodation facilities; production tools; and transportation. Furthermore, the development of the analysis that will be carried out to find a solution of capital or investment expenditures in order to reduce the occurrence of losses, it can be inventoried several things including the length of the production operation tool used; the number of employees; capital investment and the amount of bank interest earned; non-profit (profit / loss); and sensitivity analysis. Financial analysis is an analysis that compares costs and benefits to determine whether a project will benefit during the life of the project [30]. Financial analysis is an analysis that compares costs and benefits to determine whether a project will benefit during the life of the project [31]. Financial feasibility used in this study includes Net Present Value (NPV), Benefit Cost Ratio (BCR), Internal Rate of Return (IRR), and Payback Period (PBP) which can be described below:

\subsection{Net Present Value (NPV}

NPV shows the net benefits received during the project life at a certain interest rate. The calculation formula is as follows [32]:

$$
N P V=\sum_{t=1}^{n} \frac{B_{t}-C_{t}}{(1+i)}
$$

$B_{t}$ is the benefit of the project in year $\mathrm{t}(\mathrm{Rp}) ; C_{t}$ is the project cost in t-year $(\mathrm{Rp}) ; I$ is Discount factor, which is $6.00 \%$ is the interest rate of Bank Mandiri deposits that can be used by companies; and $t$ is the economic life of the project, namely for 15 years is the economic life of the longest investment (refining machine). Investment criteria based on NPV namely NPV $>0$ means that a project has been declared profitable and can be implemented; NPV $<0$ means that the project does not produce the value of the costs used (the project is detrimental and vice versa); and $\mathrm{NPV}=0$ means that the project is able to return exactly the size of the social Opportunities Cost capital of normal production factors (the project is not profitable and does not lose).

\subsection{Net Benefit Cost Ratio (Net B/C)}

Net $\mathrm{B} / \mathrm{C}$ states the amount of return for every one unit of costs incurred during the project life. Then the pattern or calculation formula for Net B/C [32]:

$$
\operatorname{Net} \frac{B}{C}=\frac{\sum_{t=1}^{n} \frac{B_{t}-B_{t}}{(1-i)}}{\sum_{t=1}^{n} \frac{B_{t}-B_{t}}{(1-i)}}
$$


$B_{t}$ is a benefit obtained every year; $C_{t}$ is the cost incurred every year; $n$ is 15 years which is seen from the economic life of the investment with the longest life, namely the refining machine; and $i$ is Discount factor (discount) used by $6.00 \%$. The investment criteria based on the Net B/C ratio is if the Net B/C $>0$ then NPV $>0$ means a profitable project; if the Net $B / C<0$ then NPV $<0$ means the project is detrimental; and if the Net $\mathrm{B} / \mathrm{C}=1$ then $\mathrm{NPV}=0$ means the project is not profitable and does not lose.

\subsection{Internal Rate Return (IRR)}

IRR is the average level of annual internal profit for a company that invests and is expressed in percent units. The IRR level reflects the maximum interest rate that can be paid by the project for the resources used. An investment is considered feasible if the IRR value is greater than the prevailing interest rate and vice versa if the IRR value is less than the prevailing interest rate, the project is not feasible. The calculation formula is as follows [32]:

$$
I R R=i+\frac{N P V}{N P V-N P V^{\prime}}\left(i^{\prime}-i\right)
$$

$i$ is a discount rate that produces a positive NPV; $i$ ' is the discount rate which produces a negative NPV; NPV is a positive NPV; and NPV' NPV which is negative.

\subsection{Payback Periode (PBP)}

PBP or return on investment is used to measure the payback period. The Payback calculation period is as follows [32]:

$$
\text { Peyback Period }=\frac{I}{A_{b}}
$$

$I$ is the amount of investment needed; and $A_{b}$ is a net benefit that can be obtained annually.

\section{Result and Discussion}

\subsection{Business Planning for Lawang Skin Oil}

Planning is a management function that relates to the strategies, policies, procedures, rules, programs and budgets needed to run a mace oil business. Conditions with the potential for the availability of raw materials that are abundant in nature, especially the many plants of lawang trees in the West Papua region, it is very possible to build a business for the processing of the lawang tree plant. The following data are the assumptions used in planning to establish a lawang oil plant business such as the ability to produce Lawang 1,200 liter/month; ability to produce Lawang oil 40 liters/day; selling price of lawang skin oil per 600 milliliters Rp. 250,000,-; the purchase price of raw material is Rp. 5,000,000,-; indications of damage to raw materials ranged from 1\%; 15 year production cycle; the business is run within 12 months; Depreciation of investment value is considered constant every year. At the end of the third year the amount of the remaining investment amount reached Rp. 1,620,912,000,- to estimate the 5 years the company operates. obtained from the depreciation value of equipment as shown in Table 2.; Materials and consumable equipment needed in a month to produce 1,200 liters of oil lawang; 
also needed marketing costs which amounted to Rp. 20,000,000,- (consisting of salary of 1 kindergarten marketing person amounting to Rp. 2,500,000,-/month; business operations are sufficient with working capital for 1 month; the total business capital costs required are Rp. $5,480,102,72,-4$; and investment is obtained from the Bank in the form of Business Credit with an interest rate of not more than $12 \%$.

\subsection{Economic Profile}

Meeting the initial investment needs of Lawang Oil, using funds sourced from own capital. The initial investment fund requirement for Lawang Oil can be seen in Table 1. Table 1. shows that the business investment fund needs for the lawang oil plant in starting its business activities is Rp. 5,480,102,724,-. To clarify the results shown in Table 1. above, the steps taken are the production costs obtained from the Total Variable Costs and the Total Fixed Costs. Furthermore, it can be seen that the source of working capital funds per day sourced from bank loans (credit) is $75 \%$ and from own funds is $25 \%$.

Table 1. Initial Investment Fund Needs For The Lawang Oil Mill In Manokwari Regency, West Papua

\begin{tabular}{lccr}
\multicolumn{1}{c}{ Description } & $\%$ & Monthly Fees (Rp) & Annual Fees (Rp) \\
\hline Production cost & & 212.012 .727 & 2.569 .152 .724 \\
Marketing Costs & & 20.000 .000 & 240.000 .000 \\
Operating costs & & & 2.670 .950 .000 \\
Bank Credit & 75 & & 4.110 .077 .043 \\
Personal funds & 25 & & 1.370 .025 .681 \\
Total Cost & & & 5.480 .102 .724 \\
\hline
\end{tabular}

It is also emphasized that the working capital required is the same as the operational costs and overhead costs for the first 12 months (except for overhead costs. Water, electricity and other bills are only calculated for one month), because revenue from the sale of new products is received after 30 days from the start of production. Able to pay taxes from net profit of $14 \%$. To carry out the lawang oil mill business, a variety of supporting components in investment are needed as described in Table 2. However, please note that each production equipment has a life span or the life of the estimated equipment is operating within a period of 5 years, with a factory warranty for 1 year, so equipment maintenance costs are needed in the amount of Rp. $15,000,000,-$. To determine the depreciation rate of a tool with the calculation of equipment prices minus the remaining project value, the results are divided by economic age.

Table 2. Planning Investment Costs for The Lawang Oil Mill Business

\begin{tabular}{lrrr}
\hline Cost Component & \multicolumn{1}{c}{ Costs (Rp) } & Depreciation (Rp) & \multicolumn{1}{c}{ Value (Rp) } \\
\hline Licensing & 20.000 .000 & & 4.000 .000 \\
Industrial Building & 900.000 .000 & 900.000 .000 & 60.000 .000 \\
Soil & 1.000 .000 .000 & & 1.000 .000 .000 \\
Truck & 259.400 .000 & 249.024 .000 & 51.880 .000 \\
PK Boat & 120.000 .000 & 118.518 .519 & 13.333 .333 \\
Motorcycle & 48.000 .000 & 47.520 .000 & 4.800 .000 \\
Cutting machine & 100.000 .000 & 96.000 .000 & 20.000 .000 \\
Enumerator & 100.000 .000 & 96.000 .000 & 20.000 .000 \\
Distillation Tool & 80.000 .000 & 76.800 .000 & 16.000 .000 \\
\hline
\end{tabular}




\begin{tabular}{lrrr} 
Telephone & 3.600 .000 & 3.564 .000 & 360.000 \\
Computer & 36.000 .000 & 34.560 .000 & 7.200 .000 \\
Name plate & 3.500 .000 & 3.360 .000 & 700.000 \\
Brand Stamp & 450.000 & 432.000 & 90.000 \\
Total & 2.670 .950 .000 & 1.625 .778 .519 & 1.198 .363 .333 \\
\hline
\end{tabular}

\subsection{Raw Material Requirements from Lawang Tree}

The business of producing Lawang Oil, this requires the main raw material, namely the lawang bark tree. This main raw material is obtained in forest areas through mountainous and valley areas. The raw material needs of lawang bark trees for 5 years of production adjusted to the cost of production can be seen in Table 3 .

Table 3. Use of Raw Materials and Production of Lawang Oil

\begin{tabular}{lcc}
\hline Year & Raw Materials (tons) & Production (liters) \\
\hline 2018 & 72 & 7.200 \\
2019 & 144 & 14.400 \\
2020 & 144 & 14.400 \\
2021 & 144 & 14.400 \\
2022 & 144 & 14.400 \\
Total & 648 & 64.800 \\
Average & 130 & 12.960 \\
\hline
\end{tabular}

\subsection{Project Cost}

Project costs include investment costs, operational costs, depreciation (depreciation), capital interest, and overhead costs. Project costs incurred by Lawang Oil during the 2018-2022 period can be seen in Table 4. Table 4. shows that the total cost of the Lawang Oil project during the period 2018-2022 is Rp. 19,767,544,535,- The use of operational costs in the 2nd to 5th year is considered to be fixed at Rp. 2,569,152,724,- where operational costs are reduced by the cost of the project land, in the first year it is considered to be operating only after the 6th month Total project costs or an average of Rp. 3,953,508,907,- per year.

Table 4. Lawang Oil Business Main Work in 2018-2022 (Rupiah)

\begin{tabular}{crcr}
\hline Investment Costs & Operating costs & Interest & Project Costs \\
\hline 2.670 .950 .000 & 1.284 .576 .362 & $10 \%$ & 3.007 .285 .638 \\
$0,-$ & 2.569 .152 .724 & $10 \%$ & 4.190 .064 .724 \\
$0,-$ & 2.569 .152 .724 & $10 \%$ & 4.190 .064 .724 \\
$0,-$ & 2.569 .152 .724 & $10 \%$ & 4.190 .064 .724 \\
$0,-$ & 2.569 .152 .724 & $10 \%$ & 4.190 .064 .724 \\
& & Total & 19.767 .544 .535 \\
& & Average & 3.953 .508 .907 \\
\hline
\end{tabular}

\subsection{Production Costs}

Production costs include manufacturing costs and non-manufacturing costs. Manufacturing costs include direct material costs, direct labor and factory overhead. Non-manufacturing costs include marketing costs, tax registration fees and social funds. Annual production costs of Lawang Oil can be seen in Table 5. (variable costs) and Table 6. (fixed costs). Table 5. shows that the total production costs incurred during the 2018-2022 period is Rp. 423,446,991,-. The average production cost per year reaches Rp. 84,689,398,-. The largest proportion of the use of costs is for manufacturing costs, which are an average of Rp. 44,331,060,- per year. Non- 
manufacturing costs in this industry average Rp. 40,358,338,-- per year. The largest proportion of production costs is for the purchase of direct materials and factory overhead costs. Manufacturing costs for direct materials are an average of Rp. 48,000,000,- per year. Average direct labor costs of Rp. 44,027,278,- per year. Factory overhead costs amount to an average of Rp. 18,272,582,- per year.

Table 5. Production Costs with Variable Costs

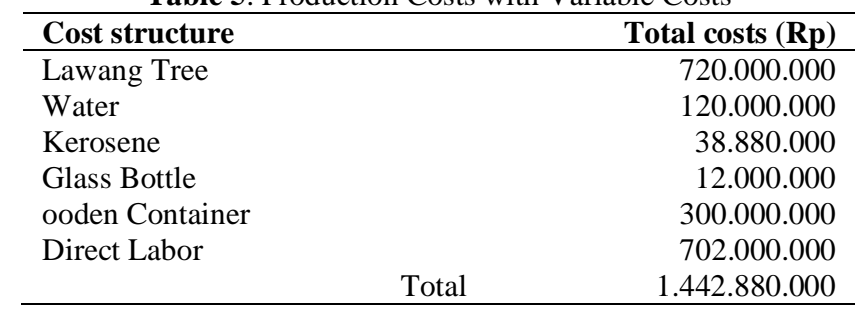

Table 6. Production Costs with Fixed Costs

\begin{tabular}{|c|c|}
\hline Cost structure & Total costs $(\mathrm{Rp})$ \\
\hline Direct Labor & 960.000 .000 \\
\hline Electricity & 57.272 .724 \\
\hline Telephone & 54.000 .000 \\
\hline ATK & 30.000 .000 \\
\hline Contribution & 10.000 .000 \\
\hline \multirow[t]{2}{*}{ Maintainance } & 15.000 .000 \\
\hline & 1.126 .272 .724 \\
\hline
\end{tabular}

\subsection{Financial Analysis}

Profit and loss analysis is intended to evaluate the results of the company's operational activities in generating profits, determining tax payments, measuring the ability to pay the company's debt and analyzing the possibility of business expansion for the company. Profit and cash flow losses in Lawang Oil can be seen in Table 7. Table 7 shows that the amount of revenue (proceeds from sales) for 5 years of production is Rp.27,000,000,000,- in lawang oil and each year is Rp. 6,000,000,000. or an average of Rp. 500,000,000,- per year. Annual revenue results are divided by 1 year from 2019-2022, but in the first year production only yields Rp.3,000,000,000,- with an average of only Rp. 250,000,000,-. The total costs incurred over a period of 5 years from 2018-2022 reached Rp. 22,886,197,910,- or an average of Rp. $428,892,649$,- per year. But in the first year the company operates the average value is Rp.191,612,563,-. Profit before tax received from the production of lawang oil annually is Rp. $853,288,212$,- or an average of Rp. 71,107,351,- per year. The first year the company operated was Rp. 700,649,243,- with an average of Rp. 58,387,437,-. The income tax that must be paid during the 5 years of the business period is Rp. 119,460,350,- of the total costs incurred by the company. The net profit earned by the company during the 5 years of its business is Rp. $733,827,862$,- or an average of Rp. $61,152,322$,- per year, and in the first year, the average is only Rp. 50,213,196,- which indicates that the business Lawang oil mills are profitable because they are able to generate profits for the company. 
Table 7. Loss of Operating Income of Lawang Oil Mills (Rp)

\begin{tabular}{lrrr}
\hline \multirow{2}{*}{ Description } & \multicolumn{3}{c}{ Years } \\
\cline { 2 - 4 } & \multicolumn{1}{c}{$\mathbf{2 0 2 0}$} & \multicolumn{1}{c}{$\mathbf{2 0 2 1}$} & \multicolumn{1}{c}{$\mathbf{2 0 2 2}$} \\
\hline Total Receipt & 6.000 .000 .000 & 6.000 .000 .000 & 6.000 .000 .000 \\
Total Expenditures & 5.146 .711 .788 & 5.146 .711 .788 & 5.146 .711 .788 \\
Distribution Costs & 240.000 .000 & 240.000 .000 & 240.000 .000 \\
Profit before tax & 853.288 .212 & 853.288 .212 & 853.288 .212 \\
Tax (14\%) & 119.460 .350 & 119.460 .350 & 119.460 .350 \\
Profit after tax & 733.827 .862 & 733.827 .862 & 733.827 .862 \\
Profit on Sales (\%) & 12,23 & 12 & 12 \\
BEP & 3.886 .951 .788 & 1.304 .629 .603 & 3.886 .951 .788 \\
\hline
\end{tabular}

\subsection{Feasibility of Company Investment}

The results of Lawang Oil financial analysis which shows that this business activity is financially profitable or feasible can be seen in Table 8. Table 8. shows that the company's NPV value at an interest rate of $10 \%$ is $0.036 \%$. This shows that the business activities carried out by the company after adjusting to the prevailing interest rate, are financially feasible to continue. Net B / C from Lawang Oil is 2.82, which indicates that the company is financially feasible to continue. Net B / C values indicate that of the costs incurred by the company, there will be a benefit of 2.82 times the cost. The IRR value of Lawang Oil is 0.023 which is higher than the capital opportunity cost. The IRR value obtained shows that the company's ability to repay loan capital in the NPV state of zero (0) is 0.036 If the company takes loan capital, the company will be able to repay the loan if the loan interest is not more than $10 \%$. The payback period value of Lawang Oil is 3.27 years. This means that the investment invested in the initial establishment of the business can return through profits received within a period of 1 year 9 months 40 days.

Table 8. Results of Lawang Business Financial Analysis in 2018-2022

\begin{tabular}{lcl}
\hline \multicolumn{1}{c}{$\begin{array}{c}\text { Investment } \\
\text { Criteria }\end{array}$} & Value & Decision \\
\hline NPV $(10 \%)$ & 0,036 & Profitable \\
Net B/C $(10 \%)$ & 2,82 & Profitable \\
IRR & 0,023 & Profitable \\
$\begin{array}{l}\text { Payback Period } \\
\text { (year) }\end{array}$ & 3,27 & Profitable \\
\hline
\end{tabular}

\section{Conclusion}

Lawang Oil Business in Manokwari Regency, West Papua Province in the estimation of operating period 2018-2022 in financial analysis can be said to be profitable. This is based on the results of the analysis of: NPV (Net Present Value) of 10\% or reaching Rp. 2,727,272,727,and Net B/C (Net Benefit Cost / Ratio) is $10 \%$ or reaches 2.82, while IRR (Internal Rate Return) is $12 \%$, and the payback period in a relatively short period is 4,5 years. Lawang's oil business in its orientation certainly has profitable prospects and can be developed as long as the selling price of the product does not exceed $8.62 \%$ and the increase in operating costs does not exceed $91.3 \%$. 


\section{References}

[1] D.J. Taukhid, Pembuatan Alat Destilasi Jahe. Yogyakarta: Universitas Gadjah Mada, 2012.

[2] Y. Sumarna, Gaharu budi daya dan rekayasa produksi. Jakarta: Penebar Swadaya, 2009.

[3] D.T. Sihite, Karakteristik Minyak Atsiri Jerangau (Acorus calamus). Sumatera Utara: Universitas Sumatera Utara, 2009.

[4] A. Sokmen et al., "The in vitro antimicrobial and antioxidant activities of the essential oils and methanol extracts of endemic Thymus spathulifolius," J. Food Control, vol. 15, pp. 627-634, 2004.

[5] A.K. Tyagi and A. Malik, "Antimicrobial potential and chemicalcomposition of Mentha piperita oil in liquid and vapour phase against food spoiling microorganisms," J. Food Control, vol. 22, pp. 1707-1714, 2011.

[6] M.E. Syahputra, D. Parasandi, and Mahfud, "Ekstraksi Minyak Nilam dengan Menggunakan Metode Microwave Hydrodistillation dan Soxlet Extraction,” J. Tek. ITS, vol. 6, 2017.

[7] E.F. Daniswara, T. I. Rohadi, and Mahfud, "Ekstraksi Minyak Akar Wangi dengan Metode Microwave Hydrodistillation dan Soxhlet Extraction,” J. Tek. ITS, vol. 6, 2017.

[8] F. R. Rangkuti, R. Agustina, Mustaqimah, and Mustafril, "Pengaruh Lama Penyulingan terhadap Rendemen dan Mutu Minyak Atsiri pada Biji Pala (Myristica fragrans Houtt)," J. Ilm. dan Penerapan Keteknikan Pertan., vol. 11, 2018.

[9] R. S. T. Mbatu, I. P. B. Kenanda, I. G. Y. Suharta, and W. S. Rita, "Aktivitas Minyak Atsiri Daun Cengkeh Sebagai Antijamur Terhadap Candida albicans,” J. Media Sains, vol. 2, 2018.

[10] R. Noveriza, M. Mariana, and S. Yuliani, "Keefektifan Formula Nanoemulsi Minyak Serai Wangi Terhadap Potyvirus Penyebab Penyakit Mosaik Pada Tanaman Nilam,” Bul. Penelit. Tanam. Rempah dan Obat, vol. 28, 2017.

[11] R.C. Rachmawati, R. Retnowati, and U. P. Juswono, "Isolasi Minyak Atsiri Kenanga (Cananga Odorata) Menggunakan Metode Distilasi Uap Termodifikasi,” J. Ilmu Kim. Univ. Brawijaya, vol. 1, 2013.

[12] M.S. Sawu, F. O. Nitbani, and R. I. Lerrick, “Analisis Minyak Kayu Putih (Melaleuca cajuputi Powell) Asal Pulau Flores," Chem. Notes, vol. 1, 2018

[13] M. Ariyanti and Y. Asbur, "Cendana (Santalum Album 1.) Sebagai Tanaman Penghasil Minyak Atsiri," J. Kultiv., vol. 17, 2018.

[14] A.R. Slamet, "Uji Patogenisitas Tiga Isolat Phytophthora Palmivora Pada Tanaman Lada, Kelapa, Cokelat Dan Panili,” Bul. Penelit. Tanam. Rempah dan Obat, vol. 6, 1991.

[15] K.S. Nugraheni, L. U. Khasanah, R.Utami, and B. K. Anandhito, "Pengaruh Perlakuan Pendahuluan Dan Variasi Metode Destilasi Terhadap Karakteristik Mutu Minyak Atsiri Daun Kayu Manis (C. Burmanii)," J. Teknol. Has. Pangan, vol. 9, 2016.

[16] R. Armando, Memproduksi 15 Jenis Minyak Asiri Berkualitas. Depok: Penebar Swadaya, 2009.

[17] P. Kusumedi and N. A. Jariyah, "Analisis finansial pengelolaan agroforestry dengan pola sengon kapulaga di Desa Tirip, Kecamatan Wadaslintang, Kabupaten Wonosobo,” J. Penelit. Sos. dan Ekon. Kehutan., vol. 7, pp. 93-100, 2010.

[18] S. Rusli, Penelitian dan Pengembangan Minyak Atsiri Indonesia. Bogor: Balittro, 1985.

[19] Badan Pusat Statitika, Industri Indonesia dalam angka. Jakarta: BPS, 2015.

[20] O. Lense, "The wild plants used as traditional medicines by indigenous people of Manokwari West Papua," Bio Divers., vol. 13, pp. 98-106, 2012.

[21] Z..F. Zhang, A. V. Rolando, and I. H. Kim, "Effect of benzoic acid, essential oils and Enterococcus faecium SF68 on growth perfor4mance, nutrient digestibility, blood profiles, faecal microbiota and faecal noxious gas emission in weanling pigs," J. Appl. Anim. Res, vol. 44, pp. 173-179, 2016.

[22] H. Merle, M. Morón, A. M. Blázquez, and H. Boira, "Taxonomical contribution of essential oils in mandarins cultivars, Biocheml," Syst. Eco, vol. 32, pp. 491-497, 2004.

[23] R. Hutagalung, W. Girsang, A. Kilay, and D. B. Paillin, "Analisis Peralatan dan Metode Kerja Berbasis Ergonomi Pada Penyulingan Minyak Kayu Putih Tradisional Sebagai Produk Andalan Di Ambon," Media Ilmuan Dan Prakt. Tek. Ind., vol. 11, pp. 147-154, 2017.

[24] Dewi Mayasari, A. Jayuska, and M. A. Wibowo, "Pengaruh Variasi Waktu Dan Ukuran Sampel Terhadap Komponen Minyak Atsiri Dari Daun Jeruk Purut(Citrus hystrix DC.),” J. Kim. Khatulistiwa, vol. 2, 2013. 
[25] I M. Oka Adi Parwata, W. S. Rita, and R. Yoga, "Isolasi dan Uji Antiradikal Bebas Minyak Atsiri Pada Daun Sirih (Piper betle Linn) Secara Spektroskopi Ultra Violet-Tampak," J. Kim., vol. 3, pp. 7 13,2009

[26] E. Mulyono, D. Sumangat, and T. Hidayat, "Peningkatan Mutu dan Efisiensi Produksi Minyak Akar Wangi Melalui Teknologi Penyulingan Dengan Tekanan Uap Bertahap,” Bul. Teknol. Pascapanen Pertan., vol. 8, 2012.

[27] L.M Calvo-Irabien, "Native Mexican aromatic flora and essential oils: Current research status, gaps in knowledge and agro-industrial potential," Ind. Crop. Prod., vol. 111, pp. 807-822, 2018.

[28] Badan Pusat Statistika, Provinsi Papua Barat Dalam Angka. Papua Barat: BPS, 2017.

[29] N. Attig, S. Cleary, S. El Ghoul, and O. Guedhami, "No Title," Institutional Invest. Horiz. investment-cashflow Sensit., vol. 36, pp. 1164-1180, 2012.

[30] K.H. Chung, T. H. McInish, R. A. Wood, and D. J. Wyhowski, "Production of information, information asymmetry, and the bid-ask spread: Empirical evidence from analysts' forecasts," J. Bank. Financ., vol. 19, pp. 1025-1046, 1995.

[31] S. Rusli S and M. Hasanah, "Cara Penyulingan Daun Nilam Mempengaruhi Rendemen dan Mutu Minyaknya," Pemberitaan LPTI, Balai Besar Tanam. Rempah dan Obat, vol. 24, pp. 1-7, 1977.

[32] Y. Indrajaya, A. Winara, M. Siarudin, E. Junaidi, and A. Widiyanto, "Analisis Kelayakan Finansial Pengusahaan Minyak Kayu Putih Tradisional di Taman Nasional Wasur, Papua,” J. Penelit. Sos. dan Ekon. Kehutan., vol. 10, pp. 21-32, 2013. 